\section{ECONOMICS}

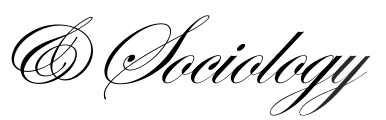

Martínez-Buelvas, L., Jaramillo-Naranjo, O., \& De la Hoz-Dominguez, E. (2021). Factors that affect quality of work life of the millennials linked to the commercial sector in Colombia. Economics and Sociology, 14(2), 71-84. doi:10.14254/2071789X.2021/14-2/4

\title{
FACTORS THAT AFFECT QUALITY OF WORK LIFE OF THE MILLENNIALS LINKED TO THE COMMERCIAL SECTOR IN COLOMBIA
}

\author{
Laura Martínez-Buelvas \\ Universidad Tecnológica de Bolivar \\ Cartagena, Colombia \\ E-mail:Imartiner@utb.edu.co \\ ORCID 0000-0002-8349-1137
}

Olga Jaramillo-Naranjo

Barranquilla, Colombia

E-mail:oljarami@gmail.com

ORCID 0000-0002-9365-4489

Enrique De La Hoz-
Dominguez
Universidad Tecnológica de Bolivar
Cartagena, Colombia
E-mail: edelaboz@utb.edu.co
ORCID 0000-0003-2531-6389

Received: August, 2020

1st Revision: February, 2021

Accepted: May, 2021

DOI: $10.14254 / 2071-$

789X.2021/14-2/4

\section{JEL Classification: O15,} M54, M12

\begin{abstract}
The present investigation has two aims: (1) to empirically examine the factors that affect QWL among the millennials working in the commercial sector in Colombia and (2) to investigate the role of a set of individual differences as moderators (for example, gender, educational level and type of contract) in a complete QWL model, based on the methodology of (Tarhini, Hone, \& Liu, 2014). The instrument used was the Work Quality of Life Tool (Wage and Subjective Conditions) which has been validated in the previous studies. The total of 1,163 surveys were conducted with workers from the commercial sector in Colombia who belong to the generation $\mathrm{Y}$ or the millennial generation, that is, born between 1981 and 2000. The results show that training, promotion, wages and the relationship of the individual with their work directly and positively affect the quality of work life in the study sample. We conduct a confirmatory factor analysis based on structural equations, revealing that the majority of the hypothesis associated with gender, educational level and type of contract were supported. This study serves to support the establishment of programs, projects and management plans to generate adequate use of the talents and skills of the millennials and thus create challenging and satisfactory jobs that increase organizational productivity.
\end{abstract}

Keywords: quality of work life, generation Y, millennials, structural equations model, human talent management

\section{Introduction}

Human talent management is a fundamental management function of any organization, which is why it has evolved to the models aimed at satisfying human capital, supported by the tools that allow developing high-performance management functions where needs and expectations of workers are at the center of management (Akranavičiūtè \& Ruževičius, 2007; Van der Berg \& Martins, 2013). In this line of thought, people represent the competitive advantage of any company, and their role is definitive in achieving the organizational objectives and goals; for this reason, the human talent area has the function of applying good management 
practices to retain, attract, motivate and help grow staff (Kultalahti \& Liisa Viitala, 2014). However, this area faces several challenges because it must respond to the needs of the employees associated with their quality of work life and their generational differences, which implies establishing an effective talent management process to achieve the desired productivity and improve workers' well-being.

In the 1970s, studies on human talent management focused on determining the intensity and characteristics of processes generating employment and on the ability to adjust work environments to improve worker performance (Carlos Iglesias, Raquel Llorente, \& Diego Dueñas, 2011; Robone, Jones, \& Rice, 2011; Sundaray, Sahoo, \& Tripathy, 2013). Thus, the movement for the quality of work life, which had been born in 1930, focused on satisfying the needs and aspirations of workers in this decade with Louis Davis and James Taylor in the West and Eric Trist, Albert Cherns and Ray Wild in Great Britain (Ahmad, 2013). Quality of work life is a dynamic and continuous process, where work is organized objectively and subjectively, in all its aspects, in order to accomplish full development of employees (Segurado Torres \& Agulló Tomás, 2002). (González, Hidalgo, \& Salazar, 2007) and (González, Hidalgo, Salazar, \& Preciado, 2010) consider that quality of work life is a multidimensional concept that is integrated when the employee sees the personal needs of institutional support, security, integration and job satisfaction covered, among others. This concept encompasses a range of programs, techniques, theories and management models to facilitate organizational design and jobs, giving workers greater autonomy, responsibility and authority (Das \& Ch, 2013). For this reason, QWL is a broad and heterogeneous concept given the richness and plurality of the different topics closely related to the work world, as a result of various disciplines, theoretical approaches and areas of study from which it can be addressed (Segurado Torres \& Agulló Tomás, 2002).

An identifiable group that shares the years of birth, age, geographic location or significant life events is called a "generation" (Martínez-Buelvas, Jaramillo-Naranjo, \& Oviedo-Trespalacios, 2019; Park \& Park, 2018; Wey Smola \& Sutton, 2002). Classifications of different generations that have entered the working world could help with understanding differences and behaviors at jobs and in companies. The millennials, or generation Y, Netters or Nexters, born between 1981 and 2000, are characterized by high expectations and preferences of a meaningful job (Martínez-Buelvas \& Jaramillo-Naranjo, 2019). They consider themselves socially responsible, tend to be questioners, like to receive feedback, and they are also confident, team-oriented, and loyal (Robbins \& Judge, 2013). Millennials grew up with technology and with the advantages that modernity brought to entertainment, education, and communication. They see themselves as capable, secure, adaptable, and digital managers. They want recognition, opportunities, trajectory, transparency, freedom and a balance between work and family life (Caraher, 2014; Wey Smola \& Sutton, 2002). They are also positive, entrepreneurial, and challenging, multitasking and goal-oriented (Fonseca, 2006). Millennials tend to be more open, liberal, practical and value personal life (Park \& Park, 2018). In addition, they prefer meaningful jobs that contribute to a greater purpose (Dixon, Mercado, \& Knowles, 2013; Martínez-Buelvas \& Jaramillo-Naranjo, 2019). Therefore, employers face the challenge of designing work environments that are stimulating, involve teamwork, with flexible schedules, with positive feedback and with excellent retention mechanisms, to attract the attention of this generation, promoting their commitment and permanence (Fonseca, 2006; Martínez-Buelvas \& Jaramillo-Naranjo, 2019).

The present investigation has two aims: (1) to empirically examine the factors that affect QWL in the millennials working in the commercial sector in Colombia and (2) to investigate the role of a set of individual differences as moderators (for example, gender, educational level and type of contract) in a complete QWL model, based on the methodology of (Tarhini et al., 
2014), in order to establish programs, projects and management plans to generate adequate use of talents and skills of this generation and thus create challenging and satisfactory jobs which would increase the effectiveness of organizations.

\section{Model design}

We propose and test a conceptual model of the perception of QWL. This model includes dimensions such as training, promotion, pay and the individual and their work activity as predictor variables, in addition to a series of individual differences as moderators (gender, educational level and type of contract) based on the methodology of (Tarhini et al., 2014). The general conceptual model is illustrated in Figure 1.

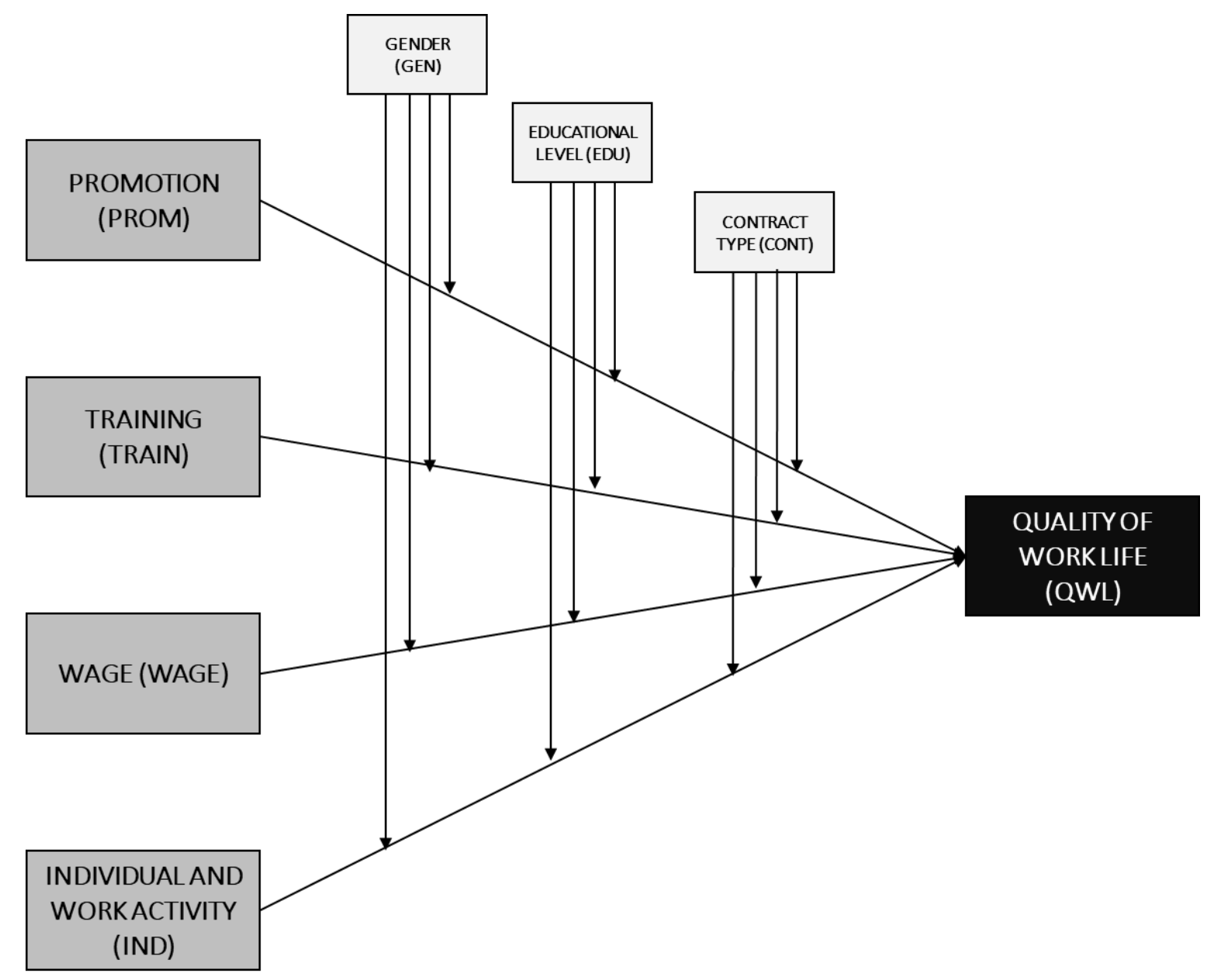

Figure 1. Conceptual model

Source: own data

\subsection{Promotion and training}

Opportunities for promotion and advancement throughout the professional career, as well as opportunities for training and research, are important motivational factors because they allow greater worker development (Casas, Repullo, Lorenzo, \& Cañas, 2002). The measurement of this variable aims to understand whether the professional profile of workers is consistent with the role they play in the organization in terms of activities or functions performed, competencies or skills developed and responsibilities assumed (Segurado Torres \& 
Agulló Tomás, 2002) Opportunities for promotion and advancement, such as training opportunities, are a motivational factor for workers because they allow personal development, greater autonomy at work and the possibility of performing more interesting and meaningful tasks (Casas et al., 2002). These are a human talent management tool and are directly related to job satisfaction, helping to retain the company's talents. Based on the above, the proposed hypotheses are:

H1. Promotion within the organization has a direct and positive effect on the perception of QWL of millennials working in the commercial sector in Colombia.

H2. The training given to workers has a direct and positive effect on the perception of QWL of millennials working in the commercial sector in Colombia.

\subsection{Wage}

Wage is one of the most valued aspects of work, but its motivating potential depends on other variables (Casas et al., 2002; Ka Wai \& Wyatt, 2007). This dimension represents the vision that workers have of their permanence in the organization, as well as their perception of growth in it or loss of employment (Cañón Buitrago \& Galeano Martinez, 2011; Robone et al., 2011). Wage is thus defined as remuneration given in the form of money or in kind to workers for making their work capacity available to the employer. It considers the perception that workers have regarding the wage received, manifesting as a motivation for their performance (Casas et al., 2002). The hypothesis associated with this variable is presented next:

H3. The perception of a good wage received by the worker has a direct and positive relationship with QWL of millennials working in the commercial sector in Colombia.

\subsection{Individual and work activity}

This dimension reflects workers' perceptions and attitudes, i.e., it represents all interpretation and/or action processes that workers perform regarding their work situation and that also affect their work well-being. However, the subjective dimension refers to the work experiences that, individually and collectively, originate a work reality within the organizational context (Quezada, Castro, \& Cabezas, 2010; Segurado Torres \& Agulló Tomás, 2002). Individual and work activity refers to the opportunities that the job offers for the use and development of knowledge, skills and abilities (Casas et al., 2002). It is a motivational factor because it produces feelings of achievement and satisfaction with oneself. For this reason, the following hypothesis is posed:

H4. The perception that millennial workers have of their work is directly related to their QWL in the commercial sector in Colombia.

\subsection{Gender}

Gender is an individual state, whether male or female, in which roles that are specific to each are described (social, cultural and physiological terms). The gender perspective appears to be a well-being strategy that should be promoted and maintained through due recognition in current societies (Contreras Estrada, Aldrete Rodríguez, \& Barrera Vega, 2015). (Ogungbamila \& Tolulope Olaseni, 2019) showed that gender is an important factor in the QWL of police 
personnel in Nigeria and that to improve their QWL, they must receive adequate work compensation. In turn, (Contreras Estrada et al., 2015) showed that women were significantly more satisfied than men with the personal development they achieved through work and with the management of their free time. However, the analysis of QWL with a gender focus is scarce in the literature; for this reason, we propose the following hypotheses for this moderator:

H5. The relationship between promotion, training and QWL is moderated by gender, such that the relationship is stronger in women than in men.

H6. The relationship between wage, individual and work activity and QWL is moderated by gender, such that the relationship is stronger in men than in women.

\subsection{Educational level}

The Ministry of National Education in Colombia defines education as "a process of permanent personal, cultural and social training based on a comprehensive conception of the human person, their dignity, rights and duties". In addition, it establishes that the Colombian educational system is made up of five levels: early education, preschool education, basic education, middle education and higher education (Ahumada \& Sanchez, 2019). The impact of this moderator relationship with QWL has not been widely investigated in the literature; for this reason, the following hypotheses are proposed:

H7. The relationship between promotion, training and QWL is moderated by educational level such that the relationship is stronger in individuals with high compared to low educational level.

H8. The relationship between wage, individual and work activity and QWL is moderated by educational level such that the relationship is stronger in individuals with high compared to low educational level.

\subsection{Type of contract}

The Colombian worker faces a phenomenon of labor flexibility in which individualized and sectoral work, subcontracting and temporary work, new working hours rules, among other aspects, prevail. (Uribe-Rodríguez, Garrido-Pinzón, \& Rodríguez, 2011). It is common in Colombian organizations to maintain a group of permanent workers and a group of contingent workers as a hiring strategy (Vesga Rodríguez, 2011). These organizational behaviors have negative effects on workers' perception of the psychosocial aspects of work and, as a result, affect organizational management. Work has the possibility of being perceived as positive or negative for workers based on their experiences in their work environment, including contractual and working conditions (Vesga Rodríguez, 2011). Next, the variables associated with the study of this dimension are presented:

H9. The relationship between promotion, training and QWL is moderated by the type of contract such that the relationship is stronger in individuals with a stable employment contract than in those without. 
H10. The relationship between wage, individual and work activity and QWL is moderated by the type of contract such that the relationship is stronger in individuals with a stable employment contract than in those without.

\section{Methodological approach}

\subsection{Procedure}

The data obtained in the present study are part of a broader investigation that evaluated where not only sociodemographic dimensions were analyzed but variables associated with wage conditions and subjective conditions associated with QWL were also evaluated.

The data were obtained through a survey requiring approximately 40 minutes to complete, which was applied by the research team, consisting of professors and students. A questionnaire was developed in Google Forms. The latter were previously trained to provide guidance to workers who required it during the evaluation session. Workers signed an informed consent form in which they were expressly told that aggregate use of the data would be made exclusively for research purposes, preserving anonymity. The workers, as well as the companies, were randomly chosen from the commercial sector in Colombia. The instrument was applied in the 2016-2017 period. The sample was intentional and the respondents were chosen randomly.

\subsection{Instrument}

In this study we used the instrument called Work Quality of Life Tool (Wage and Subjective Conditions) (Buelvas, Oviedo-Trespalacios, \& Amaya, 2016; Martínez, 2014; Martínez-Buelvas et al., 2019; Martínez-Buelvas, Oviedo-Trespalacios, \& Luna-Amaya, 2015, 2018). This tool try to understand the factors related to wage and subjective conditions that, from workers' perspective, affect their QWL. The instrument included items according to demographic conditions, perceptions about wage, subjective conditions and behavior (Martínez-Buelvas et al., 2015). Items were scored from 1 to 10 using a 10 point Likert scale (strongly disagree to strongly agree).

\subsection{Data analysis}

Descriptive statistics in the sample was applied. Then, we mainly included the analysis of the model in terms of reliability and validity. Finally, the analysis of the structural model and the testing of hypotheses was conducted.

\section{Results}

\subsection{Descriptive analysis of the sample}

A total of 1,163 surveys were conducted with workers of the commercial sector in Colombia who belong to generation Y or Millennial generation, that is, who were born between 1981 and 2000. The distribution of workers with respect to gender was $57.2 \%$ women and $42.8 \%$ men. Most of the workers have an average time working in the organization of 1 to 3 years. The distribution of company size was small and medium $(24.8 \%)$, medium $(31.8 \%)$ or large (43.4\%). Table 1 presents the relevant information of the participants. 
Table 1. Demographics separated by gender, education, experience, type of contract and company size

\begin{tabular}{|c|c|c|c|}
\hline \multicolumn{2}{|r|}{ Sociodemographic variable } & Frequency & Percentage \\
\hline \multirow{2}{*}{ Gender } & Female & 665 & $57.2 \%$ \\
\hline & Male & 498 & $42.8 \%$ \\
\hline \multirow{8}{*}{ Education } & Primary & 8 & $0.7 \%$ \\
\hline & Secondary & 254 & $21.8 \%$ \\
\hline & Technical & 338 & $29.1 \%$ \\
\hline & Technological & 151 & $13.0 \%$ \\
\hline & Professional & 349 & $30.0 \%$ \\
\hline & Specialization & 48 & $4.1 \%$ \\
\hline & Master's degree & 13 & $1.1 \%$ \\
\hline & Doctorate & 2 & $0.2 \%$ \\
\hline \multirow{5}{*}{ Experience } & Less than 1 year & 406 & $34.9 \%$ \\
\hline & 1 to 3 years & 438 & $37.7 \%$ \\
\hline & 3 to 5 years & 151 & $13.0 \%$ \\
\hline & 5 a 10 years & 119 & $10.2 \%$ \\
\hline & More than 10 years & 49 & $4.2 \%$ \\
\hline \multirow{5}{*}{$\begin{array}{l}\text { Type } \\
\text { contract }\end{array}$} & Fixed Term & 345 & $29.7 \%$ \\
\hline & Indefinite term & 642 & $55.2 \%$ \\
\hline & Occasional/Transient & 55 & $4.7 \%$ \\
\hline & Freelance & 80 & $6.9 \%$ \\
\hline & No contract & 41 & $3.5 \%$ \\
\hline \multirow{3}{*}{ Company Size } & Small and medium & 288 & $24.8 \%$ \\
\hline & Medium & 370 & $31.8 \%$ \\
\hline & Large & 505 & $43.4 \%$ \\
\hline
\end{tabular}

Source: own compilation

As we can see in Table 2, descriptive statistics analysis of the Work Quality of Life Tool (Wage and Subjective Conditions) show that the majority of the participants gave positive responses to the items measured. For the independent variables (PROM, WAGE, TRAIN and IND), all means were greater than 7.0

Table 2. Descriptive analysis of the instrument

\begin{tabular}{lccc}
\hline Variable & Mean & Std. Deviation & Cronbach's $\boldsymbol{\alpha}$ \\
\hline Promotion (PROM) & 7.55 & 0.839 & 0.93 \\
\hline Wage (WAGE) & 6.97 & 0.867 & 0.93 \\
\hline Training (TRAIN) & 7.15 & 0.690 & 0.93 \\
\hline Individual and work activity (IND) & 7.7 & 1.137 & 0.93 \\
\hline
\end{tabular}

Source: own compilation

\subsection{Analysis of reliability and validity}

A confirmatory factor analysis (CFA) based on structural equations was used, in order to examine the relationships between the hypotheses within the proposed model. The maximum likelihood method to estimate the model parameters was adopted. All analyses were performed on variance-covariance matrices. Table 3 shows the acceptance fit level and the fit indices for the sample after improving its fit. The results show that the measurement model fits the data for the proposed model. 
Table 3. Summary of model fit

\begin{tabular}{lcc}
\hline \multicolumn{1}{c}{ Fit index } & Recommended value & Structural model \\
\hline $\mathrm{X}^{2}$ & $\mathrm{NS}$ at $\mathrm{p}<0.05$ & 1987.05 \\
\hline Degrees of freedom $(\mathrm{df})$ & $\mathrm{n} / \mathrm{a}$ & 408 \\
\hline $\mathrm{X}^{2} / \mathrm{df}$ & $<5$ & 4.87 \\
\hline CFI & $>0.9$ & 0.912 \\
\hline TLI & $>0.9$ & 0.904 \\
\hline RMSEA & $<0.08$ & 0.058 \\
\hline
\end{tabular}

Source: own compilation

\subsection{Analysis of the structural model}

The same criteria used in the last item was also used to measure the goodness-of-fit for the proposed model. It is clear from the table 3, that all values were in the recommended range. The relationships of the construct were tested after supporting the validity and reliability of the measurement model. A CFA model based on structural equations was used to test all hypothetical relationships (H1 to $\mathrm{H} 10)$.

All direct hypotheses were accepted (H1, H2, H3 and H4) (see Table 4). Promotion and training have a direct and positive effect on the QWL of millennials working in the commercial sector in Colombia; however, TRAIN $(\gamma=0.432)$ is a more significant determinant compared to $\operatorname{PROM}(\gamma=0.185)$. This means that promotion and training opportunities constitute a factor of job satisfaction because they allow personal development, greater autonomy at work and the possibility of performing more interesting and meaningful tasks for workers. In turn, it was found that wage (WAGE, $\gamma=0.332$ ) has a significant influence on QWL, thus supporting H3. Last, the results associated with the interpretation and/or action processes that workers perform regarding their work situation and that also affect their work well-being were positive (IND, $\gamma$ $=0.179$ ), thus validating $\mathrm{H} 4$.

Otherwise, we can show in Table 5 that some of hypothetical relationships of the moderating effect were supported.

Table 4. Results of the direct hypotheses

\begin{tabular}{ccccc}
\hline Hypotheses & $\begin{array}{c}\text { Proposed } \\
\text { Relationship }\end{array}$ & Effect type & Path coefficient & Result \\
\hline H1 & PROM $(+) \rightarrow$ QWL & Direct effect & 0.185 & Supported \\
\hline H2 & TRAIN $(+) \rightarrow$ QWL & Direct effect & 0.432 & Supported \\
\hline H3 & WAGE $(+) \rightarrow$ QWL & Direct effect & 0.332 & Supported \\
\hline H4 & IND $(+) \rightarrow$ QWL & Direct effect & 0.179 & Supported \\
\hline
\end{tabular}

Source: own compilation 
Table 5. Results of moderating effect of individual differences

\begin{tabular}{|c|c|c|c|}
\hline H \# & Proposed Relationship & z-Score & Result \\
\hline \multirow[t]{2}{*}{$\mathrm{H} 5$} & GEN x (PROM, TRAIN) $\rightarrow$ QWL & PROM: 1.026 & Not supported \\
\hline & & TRAIN: $7.690^{* * *}$ & Supported \\
\hline \multirow[t]{2}{*}{ H6 } & GEN x (WAGE, IND) $\rightarrow$ QWL & WAGE: $5.285^{* * *}$ & Supported \\
\hline & & IND: 0.139 & Not supported \\
\hline \multirow[t]{2}{*}{$\mathrm{H} 7$} & EDU x (PROM, TRAIN) $\rightarrow$ QWL & PROM: $3.516^{* * *}$ & Supported \\
\hline & & TRAIN: $5.643 * * *$ & Supported \\
\hline \multirow[t]{2}{*}{$\mathrm{H} 8$} & EDU x (WAGE, IND) $\rightarrow$ QWL & WAGE: 0.649 & Not supported \\
\hline & & IND: 0.418 & Not supported \\
\hline \multirow[t]{2}{*}{ H9 } & $\begin{array}{c}\text { CONT x (PROM, TRAIN) } \rightarrow \\
\text { QWL }\end{array}$ & PROM: $3.516^{* *}$ & Supported \\
\hline & & TRAIN: 0.346 & Not supported \\
\hline \multirow[t]{2}{*}{$\mathrm{H} 10$} & CONT x (WAGE, IND) $\rightarrow$ QWL & WAGE: $1.959 * *$ & Supported \\
\hline & & IND: 1.832 & Supported \\
\hline
\end{tabular}

Source: own compilation

\section{Discussion}

The research question focused on examining the factors that affect the QWL of millennials working in the commercial sector in Colombia. A conceptual model was proposed that includes variables such as training, promotion, wage and the individual with their work activity. Additionally, a set of sociodemographic differences were incorporated into the model as moderators (for example, gender, educational level and type of contract). It is not surprising that all direct relationships between TRAIN, PROM, WAGE and IND with QWL were compatible at a significance level of $95 \%$. TRAIN was the factor most strongly affecting the QWL of this sample. Therefore, this study is the first to find empirical support for this type of relationship in the QWL in the Colombian context. In light of these results, human resource management should establish management practices that allow for offering excellent working conditions to foster leadership development and strengthening while maintaining the interest, morale and productivity of workers at high standards.

The results of the moderating factors are analyzed below, we can concluded that some were not supported, while others had a significant effect on the relationship between the independent variables analyzed and QWL.

\subsection{Gender}

It was found that gender moderates the relationships between TRAIN-QWL and WAGE-QWL (Table 5). This means that there is a connection between training and QWL, being more significant for women than for men, contrary to WAGE-QWL, given that this relationship is more important for men than for women. 


\subsection{Educational level}

As expected, it was shown that educational level moderates the relationships between TRAIN-QWL and PROM-QWL (Table 5), i.e., the higher the educational level, the better the perception of promotion and advancement opportunities throughout the professional career, and the same is true for training and research opportunities, constituting important motivational factors. However, hypothesis 8 was not supported in any case, which means that regardless of workers' educational level, they will always want better wage conditions and better relationships with their work.

\subsection{Type of contract}

The results show that the type of contract moderates the relationships between PROMQWL, WAGE-QWL and IND-QWL (Table 5). This means that when workers have a work contract, they will prefer to be promoted by the company to feel an improvement in their QWL. In contrast, workers without a contract prefer to be offered good working conditions, even if they are temporary, and to have a favorable work environment in which to perform.

\section{Conclusion}

Quality of work life is a construct that tends to improve the objective and subjective conditions of work and the growth and development of the human talent of an organization and therefore the achievement of greater productivity and business well-being. It is the quality of the relationship of workers with their work and the overall work environment, the concern for the impact of work on people, as well as the effectiveness of the organization and the idea of participation in the resolution of organizational problems and decision-making (Gupta \& Hyde, 2013).

It has been found that companies with good QWL levels have a greater chance of attracting and maintaining qualified, committed and motivated workers (Mejbel \& Almsafir, 2013). Therefore, the efforts of companies should be oriented toward having a work environment that leads to the achievement of satisfaction and happiness at work, promoting adequate job designs, continuous training, career and succession plans, autonomy, meaning, job stability, safety and health, good remuneration and wage benefits, balance of personal and work life, flexibility and recognition, among others, conditions that ensure a true win-win relationship between workers and their company. If current organizations guarantee these conditions, they create favorable environments to more effectively manage the different generations that coexist in it, especially millennial workers.

In agreement with the findings of the present study, the study by (González Baltazar et al., 2015), which focused on the relationship between QWL and gender and was conducted 322 individuals randomly selected in a health institution in the city of Guadalajara, found dissatisfaction among women in the face of unequal opportunities. It showed that women are significantly more satisfied than men in the personal development achieved through work and in the administration of their free time, an element that confirms our findings.

Tabassum et al., cited by (Gupta \& Hyde, 2013), compared QWL between men and women working in private commercial banks in Bangladesh through quantitative surveys of 128 male and 64 female workers. The study revealed that there is a significant difference between the QWL of male and female workers with respect to the following factors: adequate and fair compensation, flexible work schedule and job assignment, attention to job design and relations with workers. In turn, the results from a survey of temporary workers $(n=1,261)$ 
indicate that female temporary workers have more positive attitudes toward work compared to men. They also indicated that educational and, to a certain extent, age acted as moderators of the relationship between gender and worker attitudes (Selvarajan, Slattery, \& Stringer, 2015).

Regarding the connection between wage, promotion and training with QWL, (Aguirre Osorio, 2017) found that millennials prefer a not so high wage but with clear options for promotion. A total of $98 \%$ expect that these opportunities exist in the company, considering it a retention mechanism. Their sample showed that $64 \%$ had graduate training and $18 \%$ had vocational training. This confirms that the higher the level of academic training, the higher the perception of promotion or advancement for this generation.

For the millennial generation, what matters is career security. When making learning or career development decisions, young workers do not wait for the timelines of companies but rather invest their own money in educational programs that can increase their knowledge and skills in the specialty, because they know that training is the great differentiator in the work world (Molinares, 2011). Likewise, they conceive promotion opportunities as personalized, considering personal interests and based on learning and challenge. (Gupta \& Hyde, 2013) found that workers who have been promoted in the past are more satisfied and have a higher QWL compared to newcomers, who may get promoted later because they just joined the bank, denoting the impact of this process on worker satisfaction.

Regarding the type of contract, (Aguirre Osorio, 2017) found that the millennial generation values job stability, staying in the company with indefinite-term contracts if given the possibility of working in several companies and dividing their time. He also found that $96 \%$ of both men and women, since the sample was 50/50, value organizations that allow them to acquire new knowledge. In other words, they show a greater preference for group recognitions, appreciate a good work environment and interpersonal relationships, show preference for having greater autonomy in decision-making and being able to have a relationship with the boss where they can express their opinions. Last, they consider it very important to have clarity on the organizational objectives, their role and their responsibilities, understanding how the job they perform contributes to the overall achievements of the organization.

These results continue to corroborate the findings, as it is evident how generation Y or millennials demand organizational environments where: their stability is valued, the possibilities for growth in the company are constant, there is an excellent work environment and the dimensions of autonomy, recognition, permanent feedback, meaning and continuous identification with their work are present. With little tolerance for boredom, millennial workers enjoy new challenges and expect to be shown respect and given responsibility early in their careers (Glass, 2007; Martin, 2005; Yoonjoung Heo, Kim, \& Kim, 2018).

Given this scenario, it is essential for the Colombian commercial sector to make their companies attractive to millennials and understand how to keep them motivated and help them develop their careers within their organizations, given their increased entry in the labor market. Likewise, as the number of women employed in the industry also increases, the recognition of gender differences has emerged as a key issue to ensure the success and competitiveness of companies in the face of the demands of the new era goals according to the United Nations (UN) (Yoonjoung Heo et al., 2018). The knowledge of these results will allow organizations to improve their business brand by offering human management practices and processes that seek the retention, growth and development of all its members, especially for the millennial generation and those to come.

Last, this study adds value to research on QWL, as it combines wage and subjective conditions of work (wage, training, promotion, individual and work activity), with moderating factors such as gender, formal education and type of contract, elements that have not been correlated in other studies of this construct. Future studies on the relationships between QWL 
and other demographic factors or on these relationships in other economic sectors are explored and their possible implications analyzed are recommended.

\section{References}

Aguirre Osorio, P. A. (2017). Características sociodemográficas y laborales de los diferentes grupos generacionales que laboran en el año 2016, en la Central Hidroeléctrica de Caldas CHEC S.A E.S.P. Universidad San Buenaventura.,

Ahmad, S. (2013). Paradigms of Quality of Work Life. Journal of Human Values, 19(1), 73 82. doi:10.1177/0971685812470345

Ahumada, L. K., \& Sanchez, I. D. (2019). Application of the Wilcoxon Test to correlate the results of the Saber 11 and Saber T\&T Test. IOP Conference Series: Materials Science and Engineering, 519, 012034. doi:10.1088/1757-899x/519/1/012034

Akranavičiūtè, D., \& Ruževičius, J. (2007). Quality of Life and its Components' Measurement. Gyvenimo kokybe ir jos sudedamuju daliu vertinimas., 52(2), 44-49.

Buelvas, L. M., Oviedo-Trespalacios, O., \& Amaya, C. L. (2016). Design and validation of an instrument to measure the perception of working conditions: Case manufacturing sector Colombian Caribbean Region,Diseño y validación de una herramienta para medir la percepción de las condiciones de trabajo: Caso Sector manufacturero de la región Caribe colombiana. Universitas Psychologica, 15(1), 339-348. doi:10.11144/Javeriana.upsy151.dvhm

Caraher, L. (2014). Millennials en la oficina: Editorial Paidos.

Carlos Iglesias, F., Raquel Llorente, H., \& Diego Dueñas, F. (2011). Calidad del empleo y satisfacción laboral en las regiones españolas. Un estudio con especial referencia a la Comunidad de Madrid. Investigaciones Regionales(19), 25.

Casas, J., Repullo, J. R., Lorenzo, S., \& Cañas, J. J. (2002). Dimensiones y medición de la calidad de vida laboral en profesionales sanitarios. Revista de administración sanitaria, 6(23), 143-160.

Cañón Buitrago, S. C., \& Galeano Martinez, G. (2011). Factores Laborales Psicosociales y Calidad de Vida Laboral de los Trabajadores de la Salud de ASSBASALUD E.S.E. Manizales. 11(2), 114.

Contreras Estrada, M., Aldrete Rodríguez, M., \& Barrera Vega, J. (2015). Relación entre género y calidad de vida laboral en profesionales de salud. Psicogente, 18(33), n/a. doi:10.17081/psico.18.33.55

Das, T. V., \& Ch, V. (2013). Quality of Work Life - A Strategy for Good Industrial Relations. Advances in Management, 6(11), 8-15.

Dixon, G., Mercado, A., \& Knowles, B. (2013). Followers and Generations in the Workplace. Engineering Management Journal, 25(4), 62-72. doi:10.1080/10429247.2013.11431996

Fonseca, J. (2006). Conociendo la Generación Y: Educause.

Glass, A. (2007). Understanding generational differences for competitive success. Industrial and Commercial Training, 39(2), 98-103. doi:10.1108/00197850710732424

González Baltazar, R., Hidalgo Santacruz, G., Cortés, S., Contreras Estrada, M. I., Aldrete Rodríguez, M. G., Hidalgo González, B. J., \& Barrera Vega, J. A. (2015). RELACIÓN ENTRE GÉNERO Y CALIDAD DE VIDA LABORAL EN PROFESIONALES DE SALUD. Psicogente, 18, 52-65.

González, B. R., Hidalgo, S. G., \& Salazar, E. J. (2007). Calidad de vida en el trabajo: un término de moda con problemas de conceptualización. Psicología y Salud, 17(1), 115123. 
González, B. R., Hidalgo, S. G., Salazar, E. J., \& Preciado, S. M. (2010). Elaboración y validación del instrumento para medir calidad de vida en el trabajo "CVT-GOHISALO". Ciencia \& Trabajo, 12(36), 332-340.

Gupta, B., \& Hyde, A. M. (2013). Demographical Study on Quality of Work Life in Nationalized Banks. Vision: The Journal of Business Perspective, 17(3), 223-231. doi:10.1177/0972262913496727

Ka Wai, C., \& Wyatt, T. A. (2007). Quality of Work Life: A Study of Employees in Shanghai, China. Asia Pacific Business Review, 13(4), 501-517. doi:10.1080/13602380701250681

Kultalahti, S., \& Liisa Viitala, R. (2014). Sufficient challenges and a weekend ahead Generation Y describing motivation at work. Journal of Organizational Change Management, 27(4), 569-582. doi:10.1108/JOCM-05-2014-0101

Martin, C. A. (2005). From high maintenance to high productivity. Industrial and Commercial Training, 37(1), 39-44. doi:10.1108/00197850510699965

Martínez, L. (2014). Evaluación Del Impacto De Las Condiciones De Trabajo En La Calidad De Vida Laboral En El Sector Manufacturero De La Región Caribe Colombiana (Maestría en Ingeniería Industrial). Universidad del Norte,

Martínez-Buelvas, L., \& Jaramillo-Naranjo, O. (2019). How to manage generations? An Approach based on the Quality of Work Life. IBIMA Business Review, 2019, 1-15. doi:10.5171/2019.493697

Martínez-Buelvas, L., Jaramillo-Naranjo, O., \& Oviedo-Trespalacios, O. (2019). Generational diversity and quality of work life: Case study in the Colombian logistic sector. Paper presented at the Proceedings of the 33rd International Business Information Management Association Conference, IBIMA 2019: Education Excellence and Innovation Management through Vision 2020.

Martínez-Buelvas, L., Oviedo-Trespalacios, O., \& Luna-Amaya, C. (2015). Impact of working conditions on the quality of working life: Case manufacturing sector colombian Caribbean Region. Dyna. doi:10.15446/dyna.v82n194.49293

Martínez-Buelvas, L., Oviedo-Trespalacios, O., \& Luna-Amaya, C. (2018). Herramienta de evaluación del impacto de las condiciones salariales y subjetivas en la calidad de vida laboral: Caso Sector Manufacturero de la Región Caribe Colombiana. Paper presented at the Proceedings of the 32nd International Business Information Management Association Conference, IBIMA 2018 - Vision 2020: Sustainable Economic Development and Application of Innovation Management from Regional expansion to Global Growth.

Mejbel, A., \& Almsafir, M. (2013). The Drivers of Quality of Working Life (QWL): A Critical Review. Australian Journal of Basic and Applied Sciences, 7(10), 398-405.

Molinares, P. (2011). Turbulencia Generacional. : Temas Grupo Editorial .

Ogungbamila, A., \& Tolulope Olaseni, J. (2019). Gender as a Moderator of the Relationship Between Job Demand and Quality of Work-Life of Police Personnel in Lagos, Nigeria. Psychological Thought, 12(1), 63-73. doi:10.5964/psyct.v12i1.264

Park, S., \& Park, S. (2018). Exploring the generation gap in the workplace in South Korea. Human Resource Development International, 21(3), 276-283. doi:10.1080/13678868.2017.1306769

Quezada, F. Q., Castro, A. S., \& Cabezas, F. S. (2010). Diagnóstico de la Calidad de Vida Laboral Percibida por los Trabajadores de Cuatro Servicios Clínicos del Complejo Asistencial Dr. Víctor Ríos Ruiz., 9(1), 55-68.

Robbins, S. P., \& Judge, T. A. (2013). Comportamiento Organizacional (Vol. 15 ed). México: Editorial Pearson. 
Robone, S., Jones, A. M., \& Rice, N. (2011). Contractual conditions, working conditions and their impact on health and well-being. The European Journal of Health Economics(5), 429. doi:10.2307/41474380

Segurado Torres, A., \& Agulló Tomás, E. (2002). Calidad de vida laboral: hacia un enfoque integrador desde la psicología social. In (Vol. 14, pp. 828-836): Colegio Oficial de Psicólogos del Principado de Asturias 2002.

Selvarajan, T. T., Slattery, J., \& Stringer, D. Y. (2015). Relationship between gender and work related attitudes: a study of temporary agency employees. Journal of Business Research, 68(9), 1919-1927. doi:10.1016/j.jbusres.2015.01.001

Sundaray, B. K., Sahoo, C. K., \& Tripathy, S. K. (2013). Impact of Human Resource Interventions on Quality of Work Life. International Employment Relations Review, 19(1), 68-86.

Tarhini, A., Hone, K., \& Liu, X. (2014). The effects of individual differences on e-learning users' behaviour in developing countries: A structural equation model. Computers in Human Behavior, 41, 153-163. doi:https://doi.org/10.1016/j.chb.2014.09.020

Uribe-Rodríguez, A. F., Garrido-Pinzón, J., \& Rodríguez, A. M. (2011). Influencia del tipo de contratación en la calidad de vida laboral: manifestaciones del capitalismo organizacional. Revista Virtual Universidad Católica del Norte(33), 1-16.

Van der Berg, Y., \& Martins, N. (2013). The relationship between organisational trust and quality of work life. South African Journal of Human Resource Management, 11(1), 113. doi:10.4102/sajhrm.v11i1.392

Vesga Rodríguez, J. J. (2011). Los tipos de contratación laboral y sus implicaciones en el contrato psicológico. Pensamiento Psicológico, 9, 171-182.

Wey Smola, K., \& Sutton, C. D. (2002). Generational differences: revisiting generational work values for the new millennium. Journal of Organizational Behavior, 23(4), 363-382. doi:10.1002/job.147

Yoonjoung Heo, C., Kim, S., \& Kim, B. (2018). Investigating the Impact of Relationship Quality During an Internship on Millennials' Career Decisions and Gender Differences. Journal of Hospitality and Tourism Education, 30(2), 71-84. doi:10.1080/10963758.2018.1436969 